\title{
Gender and Structural Adjustment in Pakistan
}

\author{
Shahrukh Rafi Khan and Mehnaz Ahmad
}

\begin{abstract}
We review the change in the socio-economic condition of women during the intensive period of structural adjustment (1987/88 onwards) in their role as producers, as home managers and as mothers. In their role as producers, overall female labour force participation increased such that their share in the labour force virtually tripled. However, over this period there has also been a dramatic decline in female self-employment and a more dramatic rise in the female unemployment rate. In their role as home managers, women confronted a more than doubling of the sensitive price index and a cut in consumption subsidies as a percent of the budget by about two-thirds. The price of wheat, from which the poor derive almost three-fifths of their caloric intake and three-fourths, also more than doubled. In their role as mothers, data show that compared to 1987-88, education expenditure as a percent of GNP has been constant while that of health has actually declined.
\end{abstract}

\section{Introduction}

"If men and women were to take turns bearing children and if men were to bear the first, no family would have more than two children." This is a hard hitting saying by a down-to-earth woman. One could also say that if men lived the lives of poor rural or urban women for a day, they would quickly endorse a special focus on the condition of women. As things stand, in Pakistan, a special focus on women is often suspected to be driven by a foreign agenda. Even so, one needs to consider the ideological resistance to studying women and to subsequent interventions to improve their social and economic conditions.

Without quoting specific sources, it is possible to present the general view negating a special focus on women. Households are viewed as integrated units to which all contribute as teams. Women are viewed as part of households in their capacity as mothers, wives, daughters etc. Hence any independent identity for them negates this concept of an integrated household in which women play a central role for which they are accorded due respect. This is a comfortable view for men, but it denies the harsh 
social reality that women confront. There are many quotes which illustrate this harsh social reality, but the following one from the Report of a Commonwealth Expert Group on Women and Structural Adjustment (1989, p. 3) sums it up well: "Women account for half the world's population, perform two-thirds of the hours worked (though are recorded as working only one-third of those hours), received one-tenth of the world's income, and have one hundredth of the world's property registered in their name." Given such statistics, one has to be blind to basic social justice to condemn studies and policies with a special focus on women as inspired by a culturally alien foreign agenda.

The harsh social reality confronted by so many women is an important reason that justifies a special focus on women as a subject of research and as a target group. Another reason for such a special focus is that women may not share men's vision of an integrated household. There is evidence that women have opted for wage work rather than work for their husbands in order to retain control over income (Elson, 1991). This does not negate that women in general work as a team with their husbands to attain household goals. However, it suggests, as is corroborated by evidence, that women's expenditure choices are often different. Various studies have documented that women are likely to spend more on improving the nutrition, health and education of their children than men are (Onimode, 1991). This gives credence to the conceptualisation of household decision making in a cooperation-conflict framework as opposed to the more simplistic framework of new household economics that assumes a benign household head (normally male) acting in the best interests of the family. ${ }^{2}$

\section{Conceptual Framework and Method}

The Commonwealth Report suggests a useful conceptual framework for systematically presenting empirical evidence pertaining to women and structural adjustment. This framework suggests sorting information in terms of the multiple roles women perform, i.e. as producers, household managers, mothers and community organisers. ${ }^{3}$ Structural adjustment affects the nature of women's labour force participation, working hours and wage rates and hence their role as producers. It results in household reallocation decisions by affecting consumer prices and subsidies and hence their role as home managers. Finally, it affects the price and availability of social services

\footnotetext{
${ }^{1}$ Referred to in this paper as the Commonwealth Report.

${ }^{2}$ See for example Dreze and Sen (1989, pp. 56-59).

${ }^{3}$ Also see ed. Afshar and Dennis (1992), particularly the contributions of Frances Steward and Diane Elson, Tanski (1994) and Haddad et. al. (1991). In Pakistan and other developing countries, instead of viewing women as community "organisers," it may be more appropriate to study the impact of structural adjustment on womens' community "role".
} 
and hence their role as mothers. A more active community role could be a component of survival strategies that women seek in dealing with the effects of structural adjustment. ${ }^{4}$

This multiple role framework concentrates on women's current situation. In addition, structural adjustment could also affect the future ability of the current generation of girls to perform these multiple roles by more adversely affecting their nutrition, health and education than it does that of boys. Thus, evidence on comparative social statistics of children by gender is relevant to an investigation of women and structural adjustment.

Most empirical work on the impact of structural adjustment confronts the problem of establishing causality since it is impossible to replay history to see what the condition of the relevant social group would have been without structural adjustment. The lack of such a counter-factual deters only the purist, while the rest pursue other lines of inquiry making the relevant qualifications.' One such qualified line of inquiry is "beforeafter" studies. Here one has to make the assumption that the change observed by such studies can be attributed predominantly to the impact of structural adjustment. Since many other social and economic trends could be operating independently of structural adjustment, such evidence is at best viewed as circumstantial.

Our view is that it is possible to go beyond circumstantial evidence. Thus in looking at the role of women as producers in the agricultural sector, it could be possible to identify how price liberalisation affected the agricultural goods price structure and subsequently how the cropping pattern changed. Given independent information on female labour intensity by cropping patter, it would be possible to infer how structural adjustment is likely to have affected agricultural employment of women. More generally, public sector job retrenchments and a (short term) rise in unemployment induced by stabilisation measures may induce a rise in female labour force participation rates.

Again, it is possible to see how reform induced subsidy cuts changed prices of essentials and how this altered consumption patterns and nutritional intake over time. Thus, women may change consumption patterns by switching to cheaper foods, economising on fuel, cutting expenditures on consumer durables and attempting communal buying. As mothers, women may have to confront cuts in basic social services like health, education and

\footnotetext{
${ }^{4}$ This conceptual framework is useful for organising and presenting data into categories, although the originators of this framework are unlikely to assert that these are either exhaustive or non-overlapping.

${ }^{5}$ Toye (1995, pp. 13-18).
} 
water supply or deal with new user charges for such services. Cuts in social sector expenditures may raise morbidity rates, reduce life-expectancy and reduce educational attainment.

Thus it may be possible in some cases to isolate specific structural adjustment policies and investigate their gender impact. To do so, we work with a "before-after" scenario. Since the intensive period of structural adjustment reform started in $1987 / 88$, when possible we will compare the period following $1987 / 88$ to earlier periods.

\section{Evidence}

\section{a. Women as producers}

In most countries, including Pakistan, women's household work is ignored by the national accounts and women's contribution in the informal sector, where the majority of women are employed, is also under-estimated. Women supplement the family income by selling home grown vegetables and craft goods such as embroidered clothes. Alternatively, they are involved in subsistence agriculture and this contribution to the economy is also seldom recognised. Thus inadequate statistics on the contribution of women in various activities serves as a barrier in estimating the true contribution of women to the economy and hence in discerning the impact of structural adjustment policies on women as producers.

The age specific participation for the years 1969-79 and 1988-92 are reported below in Table-1.

Table-1: Labour force participation rates by age and gender

\begin{tabular}{lrc}
\hline \multicolumn{1}{c}{ Age Group } & $\mathbf{1 9 6 9 - 7 9}$ & $\mathbf{1 9 8 8 - 9 3}$ \\
\hline 10 Years \& Above & & \\
Male & 76.6 & 70.5 \\
Female & 8.3 & 12.8 \\
10-14 & & \\
Male & 32.6 & 20.1 \\
Female & 4.8 & 7.3 \\
15-44 & & \\
Male & 87.6 & 82.7 \\
Female & 9.5 & 12.1 \\
$45-60+$ & & \\
Male & 86.6 & 85.6 \\
Female & 7.7 & 11.4 \\
\hline
\end{tabular}

Source: Pakistan Economic Survey 1995-96, Statistical Appendix, p. 24. 
For the 10-14 age group, there is a very notable decline in labour force participation rates for males over the two sub-periods. This suggests a decline in male child labour which is a positive development. However, for the same age group, female labour increased by about 2.5 per cent. This selective increase in female child labour is distressing given that girl enrollment ratios are already much worse than those of boys (section $3 \mathrm{c}$ ).

Overall, male participation in the most active 15-44 age group rates declined by about 6 per cent across the two periods while there was a corresponding increase in female participation rates of 2.6 per cent $(3.7$ per cent in the 45-60 age bracket). Thus it would appear that as men were forced out of the labour force or migrated, more women entered it to compensate for the fall in household income. ${ }^{6}$ This is confirmed by looking at the gender composition of the civilian labour force which shows almost a tripling of women in the labour force over the structural adjustment period being considered.

Table-2: Selected labour force statistics by gender (percentages)

\begin{tabular}{lcccc}
\hline & \multicolumn{2}{c}{$\mathbf{1 9 8 7 - 8 8}$} & \multicolumn{2}{c}{$1993-94$} \\
\cline { 2 - 5 } & Female & Male & Female & Male \\
\hline Civilian labour force & 5.1 & 94.9 & 14.6 & 85.4 \\
Self-employed & 20.9 & 55.7 & 15.6 & 46.3 \\
Unemployed & 0.9 & 3.4 & 10.0 & 3.9 \\
\hline
\end{tabular}

Source: Labour Force Survey 1987-88 (pp. 100, 101, 137) and 1993-94 (pp. 169, 284, 200).

Table-2 above however also shows a sharp increase in the female unemployment rate from about 1 per cent to 10 per cent. Thus while many more women entered the labour force, many of them were unable to find jobs or were squeezed out by men. It also appears that over this period the ability to make ends meet by working for oneself sharply declined. There was about a 10 per cent decline in self-employment among males and about a forty per cent decline in self-employment for females. ${ }^{7}$

\footnotetext{
${ }^{6}$ For evidence on a dramatic increase in unemployment rates post 1987-88 in occupations where one could expect a high incidence of the poor, see Khan and Aftab (1993).

${ }^{7}$ Unfortunately the secondary statistics we are relying on are not reported by household head. The Household Integrated Economic Surveys however show that the reported female headed households increased from 6.07 per cent of the total in 1987-88 (p. 51) to 7.86 per cent of the total in $1992-93$ (p. 51), a thirty per cent increase.
} 


\section{b. Women as home managers}

While men allocate income for household consumption, managing and budgeting household consumption to meet basic needs is usually the responsibility of women. Inflation makes making ends meet more difficult. Table-3 below reports inflation from 1977-78 onwards with averages for two sub-periods.

Table-3: Annual percentage change in the sensitive (SPI) and general consumer price index (CPI)

\begin{tabular}{lcc}
\hline Year & SPI (12 months average) & CPI (12 months average) \\
\hline $1977-87$ & 4.6 & 4.8 \\
$1988-95$ & 10.6 & 9.8 \\
\hline
\end{tabular}

Source: Annual Report 1994-95, p. 24, State Bank of Pakistan.

Note: $1980-81$ is the base year.

The CPI coverage is confined to 464 items of mass consumption collected from 24 urban centers. The SPI is confined to 46 essential items and 47.6 per cent weight in the basket is given to low income consumers with a monthly income of Rs. 1000/-.

From being slightly lower than general inflation prior to 1987 , the SPI, became higher in the following period. Thus coping became more difficult for women in poor households.

Ironically, coping with inflation is one of the main areas of concern for structural adjustment policies and yet may components of structural adjustment induce supply side shocks that can result in a spiraling process of cost-price increases which generate self fulfilling inflationary expectations. These structural adjustment "shocks" include price increase from the reduction of subsidies especially on food items, from more general price de-controls (e.g. raising producer prices for farmers), from devaluation and from the imposition of user charges for various publicly provided services.

Table-4 below shows the subsidy cuts over the last decade. 
Table-4: Government expenditure on subsidies of major consumption goods of the poor

\begin{tabular}{lccc}
\hline Year & $\begin{array}{c}\text { Subsidies as \% of } \\
\text { Government } \\
\text { Expenditure }\end{array}$ & $\begin{array}{c}\text { Subsidies on Sugar } \\
\text { \& Wheat as \% of } \\
\text { Current Subsidies }\end{array}$ & $\begin{array}{c}\text { Subsidies on Edible } \\
\text { Oil as \% of Current } \\
\text { Subsidies }\end{array}$ \\
\hline $1985-86$ & 4.2 & 66.9 & ---- \\
$1986-87$ & 3.8 & 47.9 & --- \\
$1987-88$ & 4.4 & 49.3 & --- \\
$1988-89$ & 6.6 & 54.9 & 21.5 \\
$1989-90$ & 4.1 & 50.0 & ---- \\
$1990-91$ & 4.1 & 41.0 & 19.9 \\
$1991-92$ & 2.5 & 74.9 & 2.4 \\
$1992-93$ & 2.1 & 52.7 & --- \\
$1993-94$ & 1.4 & 70.4 & 5.5 \\
$1994-95^{\mathrm{RE}}$ & 1.5 & 53.2 & 12.5 \\
$1995-96^{\mathrm{BE}}$ & 1.3 & 9.8 & 5.2 \\
\hline
\end{tabular}

Source: Economic Survey 1995-96, Statistical Appendix, p. 141.

Notes: $\mathrm{E}=$ Revised estimate

$\mathrm{BE}=$ Budget estimate

The dramatic decline in subsidies by about two-thirds as a percentage of total government expenditure is evident from the second column of Table-4. Of more concern is the decline in subsidy to wheat and edible oil which constitutes large proportions of the caloric and protein intake for the poorest quarter of the population. Between 1987-88 and 1992-93, the consumption of cereals for the bottom 10 per cent of the population declined by 10 per cent. ${ }^{8}$ Such a decline could be expected given the decline in wheat subsidy indicated above which translated into a more than doubling of the retail price of wheat flour as reported in Table- 5 below.

\footnotetext{
${ }^{8}$ Khan, Kazmi and Ahmad (1996).
} 
Table-5: Average retail price level of wheat and wheat flour

\begin{tabular}{lcc}
\hline Year & Wheat Avg. Qty. Kg & Wheat flour Avg. Qty Kg \\
\hline $1974-81$ & 1.4 & 1.5 \\
$1988-95$ & 3.6 & 4.2 \\
\hline
\end{tabular}

Source: Economic Survey 1995-96, p. 150.

Between 1980-81 and 1994-95, food and wheat prices increased by 20 per cent more than non-food prices. Thus women as home managers in the lowest income groups have had to confront much higher prices for food in general and for wheat in particular. Our estimates also show that the poorest 25 per cent of the population derived 47 per cent and 75 per cent of their calories and protein from just wheat. ${ }^{9}$

Wages have not kept pace with price increases. Real daily wages of unskilled and skilled labour (depreciated by the food price index) declined by 15 per cent and 21 per cent respectively in Karachi, Pakistan's highest paying city. ${ }^{10}$ Entitlements and capabilities for the poor have in general declined since the start of the structural adjustment period. This includes a steep rise in the unemployment rates and a sharp fall in household incomes, which can be expected to accompany a rise in unemployment and a fall in real wages.

Based on perceptions about intra-household bargaining power, one might expect that the nutritional fallout of a decline in entitlements and capability to be worse for girls and women. Past evidence we were able to muster is reported below in Table-6 and it does not support such a view.

Table-6: Percentage under 70 per cent of recommended daily allowance (RDA) of calories by gender

\begin{tabular}{lcccccc}
\hline Year & $\begin{array}{c}\text { Adult } \\
\text { male }\end{array}$ & $\begin{array}{c}\text { Adult } \\
\text { female }\end{array}$ & $\begin{array}{c}\text { Boys } \\
\text { 6-15 } \text { yrs }\end{array}$ & $\begin{array}{c}\text { Girls } \\
\text { 6-15 } \text { yrs }\end{array}$ & $\begin{array}{c}\text { Boys } \\
\mathbf{0 - 5} \text { yrs. }\end{array}$ & $\begin{array}{c}\text { Girls } \\
\mathbf{0 - 5} \text { yrs. }\end{array}$ \\
\hline $1976-77$ & 27 & 20 & na & na & na & na \\
$1985-87$ & 32 & 18 & 28 & 18 & 34 & 30 \\
\hline
\end{tabular}

Source: $\quad$ Mciro Nutrient Survey 1976-77, p. 40; National Nutrition Survey Report 1985-87, p. 103.

Note: The finding of the 1976-77 survey are based on 1,000 households while those of the 1985-87 survey are based on 8,334 households.

\footnotetext{
${ }^{9}$ ibid.

10 ibid.
} 
The Table above shows that the nutritional intake of adult females exceeded that of males and that it improved over time while that of males declined. ${ }^{11}$ The numbers for 1985-87 also show that girls nutritional input was better than that of boys. ${ }^{12}$ More recent evidence is unfortunately not available by gender disaggregation.

\section{c. Women as Mothers}

The more the state divests its social sector provision to the private sector, the greater the burden on poor mothers in preparing the young for future survival. Structural Adjustment Programmes, with their emphasis on budget cutting, have been severely criticised in the past for the collapse in public social sector expenditure which has imposed a greater burden in the role of women as mothers. Probably in response to this criticism, in which Cornia, Jolly and Stewart (1987) are particularly influential, Structural Adjustment Programme budget cutting started protecting basic social sector expenditures.

In Pakistan, this protection has taken the form of the Social Action Programme (SAP) which is designed to concentrate massive expenditures on basic education and health and sanitation to eradicate various imbalances such as the gender and rural-urban imbalance in schooling. ${ }^{13}$ SAP became operational in 1992-93 so one could consider 1991-92 as a benchmark year. Table-7 shows how the share of expenditure on education and health has changed since the structural adjustment and the SAP periods. Our interest here is in the total sector allocation to ascertain if the SAP represented a net reallocation to these sectors or if it induced a sectoral reallocation.

\footnotetext{
${ }^{11}$ As is now well known, the numbers in Table 6 are very crude indicators of aggregate nutrition security since they make no allowance for age or gender. However, even if they did, caloric intake is still a very crude approximation for nutrition security for many reasons including different dietary needs across different individuals at a point in time and across time.

${ }^{12}$ Alderman and Garcia (1993, p. 83) also expressed surprise at their finding of gender having no statistically significant impact on nutritional status for children. We conferred with Dr. D.S. Akram, who is a nutritional expert at the Dow Medical College and Civil Hospital in Karachi, for a possible answer to this puzzle. Her response was that her own studies, based on patients in the Hospital and squatter communities, consistently show the nutritional status of girls to be worse than that of boys. The evidence reported in Table-9 also supports the latter view. A more conclusive answer will follow from further research.

${ }^{13}$ For an official statement see Economic Survey 1992-93, pp. 137-144.
} 
Table-7: Expenditure on education and health as a percentage of GDP

\begin{tabular}{lccc}
\hline Year/Expenditure & $\begin{array}{c}\text { Education } \\
\text { expenditure as a } \\
\text { percentage of GDP }\end{array}$ & $\begin{array}{c}\text { Health expenditure } \\
\text { as a percentage of } \\
\text { GDP }\end{array}$ & Total \\
\hline $1987-88$ & 2.4 & 1.0 & 3.4 \\
$1988-89$ & 2.4 & 1.0 & 3.4 \\
$1989-90$ & 2.2 & 0.9 & 3.1 \\
$1990-91$ & 2.1 & 0.7 & 2.8 \\
$1991-92$ & 2.2 & 0.7 & 2.9 \\
$1992-93$ & 2.2 & 0.7 & 2.9 \\
$1993-94$ & 2.2 & 0.7 & 2.9 \\
$1994-95$ & 2.4 & 0.6 & 3.1 \\
$1995-96$ & 2.5 & 0.8 & 3.3 \\
\hline
\end{tabular}

Source: Pakistan Economic Survey 1995-96, Statistical Appendix, p.7.

The Table above indicates that for both education and health, SAP has meant a net addition to the sectors since total expenditures since 199192, the benchmark year, have increased by 3 and 4 per cent of GNP respectively in 1995-96. ${ }^{14}$ Even so, educational expenditure as a percentage of GNP in 1995-96 barely caught up with the structural adjustment base year of 1987-88 while health expenditure in 1995-96 as a percentage of GNP was still below that in 1987-88. Input in the form of expenditure are important, but progress in any sector must be measured by looking at output data.

Table-8 shows the progress in school enrollment over benchmark years and over the SAP time period.

\footnotetext{
${ }^{14}$ One could also take the position that SAP should be given credit for preventing a decline in social sector expenditures and for re-ordering priorities without a powerful indigenous lobby calling for it.
} 
Table-8: School participation rates by level and gender

\begin{tabular}{lcccccc}
\hline \multicolumn{1}{c}{ Level } & \multicolumn{2}{c}{ Primary } & \multicolumn{2}{c}{ Middle } & \multicolumn{2}{c}{ High } \\
\hline Year/gender & Female & Male & Female & Male & Female & Male \\
\hline $1987-88$ & 48 & 80 & 19 & 41 & 10 & 24 \\
$1991-92$ & 49 & 83 & 30 & 59 & 17 & 37 \\
$1992-93$ & 54 & 85 & 30 & 58 & 18 & 38 \\
$1993-94$ & 55 & 86 & 31 & 58 & 19 & 38 \\
$1994-95$ & 55 & 87 & 31 & 58 & 20 & 38 \\
$1995-96$ & 57 & 89 & 32 & 59 & 22 & 42 \\
\hline
\end{tabular}

Source: For 1987-88, Seventh Five Year Plan, Statistical Appendix, pp. 414-415 and for 1991-92 to 1995-96, Economic Survey 199596, p. 111.

There was a sizable jump in female primary enrollment in 1992-93 compared to 1991-92, the benchmark year. Thus the concerted focus of the SAP on female primary schooling does show up in the numbers. Boys primary enrollment rates have also shown steady progress. However, the big gains for both girls and boys at both the middle and higher level between 1987-87 and 1991-92 have tapered off.

Some comparison to other countries puts these enrollment numbers in perspective. Pakistan is still poorly lagging behind even by South Asian standards. For example, the participation rate at the primary leve1 in 1992 for low income economies was 102 per cent and for India it was 98 per cent. ${ }^{15}$ The secondary enrollment for low income countries is reported in the World Development Report 1995 (1995, p. 216) to be 41 per cent which is almost double the rate cited for Pakistan (21 per cent). Also, between the benchmark year, 1991-92, and 1994/95, the gender gap in absolute terms closed slightly at the primary level but were unchanged at the middle and higher levels.

In any case, enrollment represents only half the battle and retention the other important half with regard to which Pakistan has not been doing well. While about seventy seven per cent of boys and girls who ever attended school complete class five, less than half complete the eighth class

\footnotetext{
${ }^{15}$ World Development Report 1995 (1995, p. 216). Note that this source cities Pakistan's total primary enrollment rate for 1992 to be 46 per cent.
} 
and less than a third matriculate. ${ }^{16}$ Thus while there has been some progress with regard to the support available to mothers in educational provision it has been slow and the levels attained are poor even by South Asian and low income country standards, despite the Social Action Programme. As in the case of education, we concentrate on children's health output statistics in Table-9 below.

Table-9: Childhood mortality rates by gender

\begin{tabular}{lcccc}
\hline Childhood Mortality & \multicolumn{2}{c}{ 1965-79* } & \multicolumn{2}{c}{ 1981-91@ } \\
\hline Gender & Boys & Girls & Boys & Girls \\
\hline Neonata1 Mortality (<1 Month) & 79 & 70 & 60 & 46 \\
Infant Mortality (0-11 Months) & 120 & 117 & 102 & 86 \\
Child Mortality (1-5 Years) & 44 & 48 & 22 & 37 \\
\hline
\end{tabular}

Sources: * Sathar $(1987$, p. 355$)$

@ Ahmad, Bhatti and Bicego (1992, pp.118).

Mortality rates could be viewed as a summary health statistic. Girls natural advantage of higher survival rates at an early age show up in lower and more rapidly declining neo-natal and infant mortality rates. However, this natural advantage is already offset, possibly via intra-household food allocation, in early childhood and this shows up in lower and more rapidly declining boy child mortality rates relative to those of girls.

Apart from the gender differentials, Table-9 above indicates that children's health and hence mortality indicators improved in the period that coincides with the structural adjustment period compared to an earlier period. However, much of the credit for this could be attributed to the Expanded Programme of Immunisation (EPI) which was launched in 1979 and accelerated in $1982 .{ }^{17}$ While significant improvements have been made, Pakistan lags behind other low income countries even in prominent health indicators as in the case of education. For example, the less than 5 year child mortality rate (per 1000 live births) of 129 for girls and 142 for boys for the year 1992 is much more than the average of 102 and 114 respectively for low income countries. ${ }^{18}$

\footnotetext{
${ }^{16}$ Pakistan Integrated Household Survey, Final Results (1992, p. 72).

${ }^{17}$ Pakistan Economic Survey 1993-94, p. 110 and Cornia (1996).

18 World Development Report 1994, p. 214. Also, the infant mortality rate of 92 (per 1000 live births) in 1994 for Pakistan was much higher than the corresponding rate of 58 for low income countries (World Development Report 1996, p. 198).
} 
The role of women as mothers has been facilitated indirectly by the improvement of children's health and also more directly by the improvement in their own health. This is evident from the decline in the material mortality rate (per 100,000) from 500 in the $1980-87$ period to 270 in $1988-93 .{ }^{19}$ Recent progress in women and childrens' health has been made despite a decline in health expenditure. However, with this low level of commitment, Pakistan is unlikely to be able to even match, on various indicators, the health standards of low income countries.

\section{Summary and Conclusions}

We review the impact of structural adjustment on the role of women as producers, as home managers and as mothers. In most cases, it is very difficult to isolate the effects of structural adjustment from the effects of other social and economic changes in society. However, in some cases, the chain of causality can be identified and we have attempted to do so wherever possible. In other cases, we merely compare the social and economic status of girls and women in an earlier period to the period following 1987-88 when the intensive bout of structural adjustment was underway in Pakistan.

Overall, female labour force participation in the 1988-93 period was 4.5 per cent higher than in the 1969-79 period and between 1987-88 and 1993-94 their share in the civilian labour force increased about threefold. Simultaneously, there was a corresponding decline of 6 per cent in the male labour force participation rate over these periods. While there are reasons to applaud a rise in the female labour force participation rate, this statistic in conjunction with two others puts a bleak slant on the socio-economic status of the poor. First, over the $1987-88$ to $1992-93$ period, there has been a decline of 8.2 per cent in female self-employment. Second, there has been a decline of 8.2 per cent in female self-employment. Second, there has been an increase in the female unemployment rate from 9 to 10.3 per cent over this period. Thus while it seems that women are being forced to enter the labour force to compensate for male unemployment, migration and subsequent fall in household income, the opportunities for attaining employment are not as readily available. If wage work were to lighten the domestic burden of child and home care, it may be welcome given the increased bargaining power in the household this can accompany. This however is unlikely to be the case in Pakistan's current cultural milieu. ${ }^{20}$

19 Human Development Report 1992, p. 148 for the 1980-87 number and World Development Report 1995, p. 218 for the 1988-93 number.

${ }^{20}$ Thus the term triple burden for women has been coined indicating labour market, child care and home care responsibilities. 
Another negative aspect of the labour force participation statistics are that in the 10-14 age group, female labour force participation ratio increased by 2.5 per cent (from 4.8 per cent to 7.3 per cent). This increase in female child labour occurred across the 1969-79 to 1988-93 time periods when boys' labour force participation rates in this age group dropped by over one third from 33 per cent to 20 per cent. Since boys school enrollment rates are already much higher than those of girls, this trend for girls is doubly unwelcome.

As home managers, women have had to confront several hardships. The doubling of the sensitive price index from 4.6 per cent to 10.6 per cent between 1977-87 and 1988-95 made it difficult to make ends meet at a time when joblessness was rising. While structural adjustment can not directly be blamed for this inflation, it could have contributed to the costprice spiral and rising inflationary expectations via the devaluation, user charges, price de-control and cuts in consumption subsidies.

Between 1985-86 and 1995-96, consumption subsidies as a per cent of the budget declined by about two-thirds. The subsidy to wheat and sugar as a per cent of the total declined by 86 per cent and the subsidy to edible oil declined by over three-fourths from 22 per cent to 5 per cent. As expected, the retail price of wheat doubled between the 1974-91 and 198894 periods. This probably led to a decline in the consumption of wheat by about one-tenth between 1987-88 and 1990-91 for the poorest income group. Research has shown that the poor in Pakistan derive about threefifths of their calories from wheat and so this consumption decline could be of concern.

Women's role as mothers is facilitated by social sector provision. Structural adjustment faced hostile criticism in the 1980s for inducing budget cuts and letting the burden fall on the social sectors. The philosophy underlying the UNICEF inspired Adjustment With a Human Face seems to have been absorbed by the World Bank and it is endorsing and partially funding social safety nets such as the Social Action Programme (SAP) in Pakistan. SAP has a particular focus on rural women and girls. We looked at expenditure on education and health to investigate if SAP represented an additionality or whether it simply reallocated existing social sector expenditure. Data show that compared to 1991-92, the SAP benchmark year, education and health expenditure as a per cent of GNP have increased but if 1987-88 is used as a benchmark, educational expenditure has remained constant while health expenditure has declined.

The SAP reallocation towards rural girls shows up in a 5 per cent increase in rural primary girls enrollment from 49 to 57 per cent between 
1991-92 and 1995-96. These enrollment rates however are way below the mean for low income countries and comparable enrollment rates in India. Also, enrollments and gender gaps at the middle and high levels have been virtually static.

Overall, there is little positive to report about the socio-economic condition of women during the recent intensive phase of structural adjustment. The decline in the maternal mortality rate and infant mortality rates are the exceptions. It is encouraging to read that improving the status of women and girls appears to be on the agenda of donors and of the Government of Pakistan. This expressed concern needs to show up in the numbers. 
94 The Lahore Journal of Economics, Vol.1, No.1

\section{References}

Alderman, H. and Marito Garcia, 1993, "Poverty, Household Food Security and Nutrition in Rural Pakistan" Research Report No. 96. International Food Policy Research Institute, Washington, D.C.

eds. Afshar, H., and C. Dennis, 1992, Women and Adjustment Policies in the Third World, London: MacMillan).

Ahmad T., M. Bhatti and G. Bicego, 1992, "Infant and Child Mortality," in Pakistan Demographic and Health Survey 1990-91, Islamabad: National Institute of Pakistan Studies.

Common Wealth Secretariat, 1989, Engendering Adjustment for the 1990s: Report of a Commonwealth Group on Women and Structural Adjustment, Commonwealth Secretariat.

Cornia, G.A., Accelerating Human Development in Pakistan, in eds. Banuri, T., S.R. Khan and M. Mahmood, Just Development: Protecting the Vulnerable and Promoting Growth, Karachi: Oxford University Press, forthcoming.

Cornia, G.A., R. Jolly and F. Steward, 1987, Adjustment with a Human Face: Protecting the Vulnerable and Promoting Growth, Oxford: Oxford University Press.

Dreze, J.H., and A. Sen, 1989, Hunger and Public Action, New York: Oxford University Press.

Elson, D., 1991, "Male Bias in Macroeconomics: The Case of Structural Adjustment," in D., Elson, ed. Male Bias in the Development Process, Manchester: Manchester University Press.

Government of Pakistan, Economic Surveys, Finance Division, Islamabad, various issues.

Government of Pakistan, Household Income and Expenditure Survey 198485 , Federal Bureau of Statistics, Economic Affairs Division and Statistics Division, Karachi.

Government of Pakistan, Household Integrated Economic Survey 1990-91, Federal Bureau of Statistics, Economic Affairs Division and Statistics Division, Karachi. 
Government of Pakistan, 1978, Micro-Nutrient Survey 1976-77, Nutrition Cell, Planning and Development Division, Islamabad.

Government of Pakistan, 1988, National Nutrition Survey 1985-87 Report, National Institute of Health, Islamabad.

Government of Pakistan, 1992, Pakistan Integrated Household Survey: Final Results, Federal Bureau of Statistics, Economic Affairs Division and Statistics Division, Islamabad.

Haddad, L., L. R. Brown, A. Richter and L. Smith, 1995. The Gender Dimension of Economic Adjustment Policies: Potential Interactions and Evidence to Date, in World Development, Vol. 23, No. 6, pp. 897-912.

Khan, S. R., and S. Aftab, "Structural Adjustment, Labour and the Poor," forthcoming in proceedings of a conference organised by the South Asia Forum in Dhulikhel, Nepal, July 9-21, 1994.

Khan, S. R., S. Kazmi and Z. Ahmad, 1996. Structural Adjustment and Food Security in Pakistan: An Aggregate Analysis, SDPI, mimeo.

Onimode, B., 1991, The Impact of Structural Adjustment on Women in Nigeria, in Women and Structural Adjustment: Selected Case Studies, Commissioned for a Commonwealth Group of Experts, Commonwealth Economic Papers.

Sathar, Z. A., 1985, "Infant and Child Mortality Rates in Pakistan: some Trends and Differentials," in Journal of Biosocial Science, Vol. 17, pp. 351-359.

Tanski, J. M., 1994, The Impact of Crisis, Stabilization and Structural Adjustment on Women in Lima, Peru, World Development, Vol. 22, No. 11, pp. 1127-1642.

Toye, J., 1995. Structural Adjustment and Employment Policies: Issues and Experience, Geneva: ILO.

UNDP, Human Development Report 1992, New York: Oxford University Press.

World Bank, World Development Report 1995, New York: Oxford University Press. 